\title{
Kimberlites: the Products of Deep-Seated Subduction
}

\author{
McCandless, T.E. 1
}

1. Center for Mineral Resources, Department of Geosciences, University of Arizona, Tucson, Arizona, USA 85721

With the general acceptance of the Plate Tectonic Theory over 25 years ago, most igneous rock assemblages were recognised to characterise some aspect of either rifting, subduction, or hot spot activity (e.g., MORB, OIB). Kimberlites (and related rocks), though significant as primary sources of diamond and mantle-derived xenoliths, are positioned far inland from plate margins, and were generally excluded from tectonic interpretation. Sharp (1974) proposed that kimberlites were related to subduction, as have Helmstaedt and Gurney $(1984,1997)$. However, three problems have prevented any clear correlation being drawn between kimberlite activity and plate tectonics. (1) The lack of accurate dates for kimberlite magmatism made it difficult to recognize any spatial-temporal trends that could be correlated with plate motion; (2) seismic evidence suggested that subducted oceanic lithosphere lost its physical integrity within a few hundred kilometers from the trench (Toksöz, 1975); and (3) it was considered improbable that the fluids essential for triggering magmatism could be carried deep into the mantle.

These complications can now be addressed in the following manner: (1) Accurate dating of kimberlite fields in southern Africa and North America has progessed to the point that temporal patterns can be recognised in both cases (Helmstaedt and Gurney, 1997; McCandless, 1997). (2) Seismic imaging of the Farallon Plate beneath North America demonstrates that subducted oceanic lithosphere can be recognised several hundred kilometers inboard from its site of subduction (Grand et al., 1997). (3) Experimental and physical evidence suggests that fluids can be carried deep into the mantle in dense hydrous silicates (Bose and Ganguly, 1995), possibly to be involved in diamond formation itself (Navon et al., 1988; Schrauder and Navon, 1994). The purpose of this paper is to present a tectonicthermal model that explains the spatial-temporal patterns of kimberlitic magmatism over a period of earth history when relative plate motions are best known, i.e., from $200 \mathrm{Ma}$ to present.

Toksöz (1975) recognized that depressed heat flow above convergent margins must be due to the subduction of cold oceanic lithosphere into the warm mantle, and produced a model to demonstrate the thermal and chemical changes. To account for kimberlitic magmatism, the slab is extended several hundred kilometers inland and below the continental lithosphere (Figure 1a). At time $t_{1}$ and a constant velocity $\mathrm{V}_{1}$, the isotherms are depressed in the cold descending slab, allowing fluids to reach greater depths before being heated enough to be released and trigger kimberlitic magmatism. Changes in plate convergence at time $t_{2}$ result in a reduction in velocity $\left(V_{2}<V_{1}\right)$; isotherms begin migrating up the slab, fluids are released and trigger mantle magmatism that at the surface becomes progressively younger from right to left (Figure 1b).

Applying this model to southern Africa, prior to $140 \mathrm{Ma}$, active subduction off the west coast of Gondwana placed oceanic lithosphere far beneath the continent (Figure 2a). During this period, kimberlites are restricted to south central Gondwana, where the subducted oceanic lithosphere is deep enough to reach the temperature necessary to release the fluids for kimberlitic magmatism. Rifting of the south Atlantic at 130 prevents further subduction beneath southern Africa (Figure $2 \mathrm{~b}$ ). The convergence velocity between eastern Gondwana and the subducted proto-Pacific drops to near zero, thus disturbing the thermal equilibrium in the slab. Heat migrates up the foundered oceanic lithosphere from its deepest (hottest) end, volatiles are driven off, triggering a westward migration of kimberlitic magmatism (Figure $2 b$ ).

Volume and area considerations also require that enormous amounts of oceanic lithosphere have been subducted beneath North America in the past $200 \mathrm{Ma}$. Although kimberlite ages are less wellconstrained, and the convergence between the Farallon, Kula and North American plates has varied 
considerably, temporal-spatial patterns can be recognised. From 175-125 Ma, the Farallon Plate was subducted in an eastern to southeastern direction, with velocity decreasing by a factor of two (Cox et al., 1989). Kimberlites emplaced during this period of fast to slow convergence are located along the easternmost region of the continent (Quebec, Ontario, Michigan, $150 \mathrm{Ma}$ ). Convergence shifts northward and increases between 125 to $75 \mathrm{Ma}$; widespread kimberlitic magmatism associated with the Laramide orogeny reaches far to the north (Somerset Island, Slave Province, Alberta, Saskatchewan) and east (Arkansas, Kansas). Convergence decreases dramatically from 125 to $25 \mathrm{Ma}$ and heat migrates up Farallon Plate from its deepest end. A wholesale migration of kimberlitic magmatism to the south and west ensues, culminating in lamproitic magmatism in the southern Wyoming craton (Leucite Hills; 1-3 Ma ).

Kimberlites can thus be attributed to deep subduction magmatism, and temporal-spatial patterns can be linked with changes in convergence between oceanic and continental lithospheric plates. Calcalkaline magmatism in the distant geologic record is often used in reconstruction of paleo-plate boundaries and directions of subduction; kimberlite magmatism may also serve to identify the presence of far-reaching subduction, where no other evidence is preserved.

\section{References}

Bose, K. and Ganguly, J., 1995, Experimental and theoretical studies of the stabilities of talc, antigorite, and phase $\mathrm{A}$ at high pressures with applications to subduction processes: Earth Planet. Sci. Lett., 136, p.109-121.

Cox, A. Debiche, M.G. and Engebretson, D.C., 1989, Terrane trajectories and plate interactions along contiental margins in the north Pacific Basin: In: Z. Ben-Avraham (Ed.) The Evolution of the Pacific Ocean Margins, pp.20-35, Oxford Press, New York.

Helmstaedt, H.H., and Doig, R., 1975, Eclogite nodules from kimberlites of the Colorado Plateau: Samples of subducted Franciscan-type oceanic lithosphere: Phys. Chem Earth, 9, p.95-111.

Helmstaedt, H.H. and Gurney, J.J., 1984, Kimberlites of southern Africa - are they related to subduction processes?: in Kimberlites and Related Rocks, pp.425-438, Elsevier, Netherlands.

Helmstaedt, H.H. and Gurney, J.J., 1997, Geodynamic controls of kimberlites - what are the roles of hotspot and plate tectonics?: In: N.V. Sobolev and R.H. Mitchell (Eds.) 6th International Kimberlite Conference Volume 2, Diamonds: Characterization, Genesis and Exploration. Russian Geology and Geophysics, 38, pp.394-404, Allerton Press, New York.

Grand, S.P., van der Hilst, R.D. and Widiyantoro, S., 1997, Global seismic tomography: a snapshot of convection in the Earth: GSA Today, 7, p.1-7.

McCandless,T.E., 1997, Diamond genesis and distribution through time: is there a pattern?: Geol. Soc. America Abs. with Progs., 29, p.A15.

Navon, O., Hutcheon, I.D., Rossman, G.R. and Wasserburg, G.J., 1988, Mantle-derived fluids in diamond micro-inclusions: Nature, 335, p.784-789.

Schrauder, M. and Navon, O., 1994, Hydrous and carbonatitic mantle fluids in fibrous diamonds from Jwaneng, Botswana: Geochim. et Cosmochim. Acta, 58, p.761-771.

Sharp, W.E., 1974, A plate-tectonic origin for diamond-bearing kimberlites: Earth. Planet.Sci. Lett., 21 , p.351-355.

Toksöz, M.N., 1975, The subduction of lithosphere: in, Continents Adrift and Continent Aground, pp.113-122, Freeman \& Co., San Francisco, California. 
Figure 1.
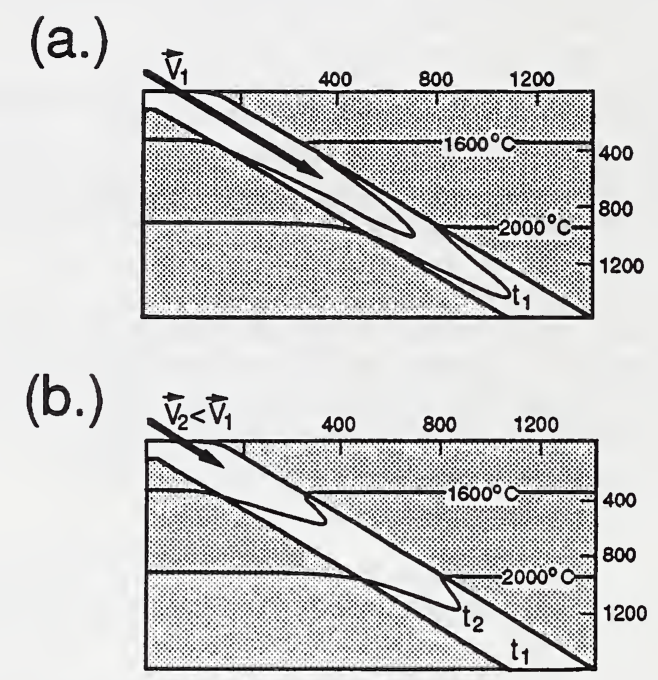

Figure 2.

(a.)

Gondwanaland

$>130 \mathrm{Ma}$

subduction zone

$250-500 \mathrm{Ma}$

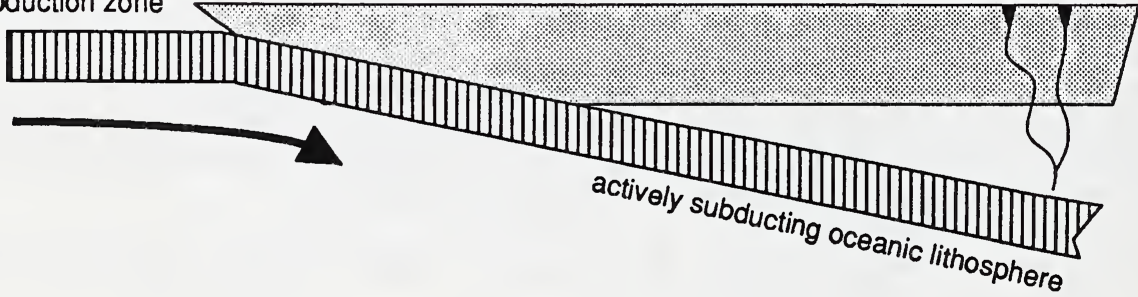

(b.)

Gondwanaland

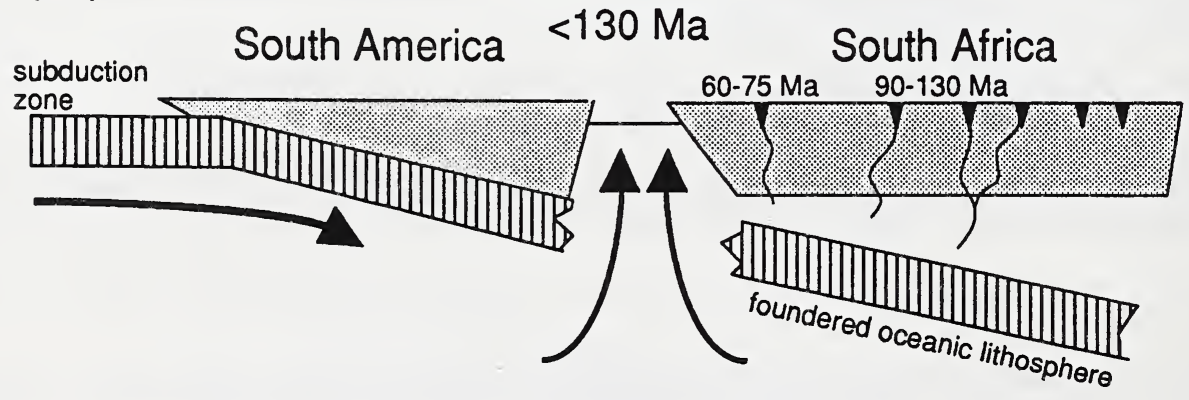

